\title{
Soil Treatments for the Potential Elimination of Phytophthora ramorum in Ornamental Nursery Beds
}

\author{
L. E. Yakabe and J. D. MacDonald, Department of Plant Pathology, University of California, Davis 95616
}

\begin{abstract}
Yakabe, L. E., and MacDonald, J. D. 2010. Soil treatments for the potential elimination of Phytophthora ramorum in ornamental nursery beds. Plant Dis. 94:320-324.

Ramorum leaf blight, caused by Phytophthora ramorum, has reemerged at several California nurseries after removal of infested material. In many cases, reemergence was not associated with reintroduction of the pathogen and may be attributed to inoculum surviving in soil beds because $P$. ramorum propagules can survive for over a year in soil. Using artificially infested soil in microcosms, fumigation and heat treatments were examined as potential eradicants of $P$. ramorum from soil. Treatments with chloropicrin, Vapam, and iodomethane were effective in reducing $P$. ramorum propagules below detection limits. Basamid was consistently effective only when fully incorporated into the soil. Application of Basamid (392 kg/ha) at infested ornamental nursery sites mirrored results from microcosm experiments, indicating that a tarp cover over treated soil is necessary for reliable efficacy. Dimethyldisulfide, 1,3-dichloropropene, and two formulations of hydrogen dioxide were less effective, resulting in only partial reduction of propagules. In heat treatments, $P$. ramorum in soil microcosms remained detectable 42 days after microcosms were incubated at 30 and $22^{\circ} \mathrm{C}$ but was not detectable in soil heated above $40^{\circ} \mathrm{C}$ for 3 days. Results from a solarized field plot indicate that prolonged sublethal temperatures, between 35 and $40^{\circ} \mathrm{C}$ for 42 days, can be effective in eliminating detectable propagules of P. ramorum.
\end{abstract}

Phytophthora ramorum is thought to be a pathogen introduced to the west coast of the United States and, prior to its discovery as the cause of tree mortality in coastal California woodlands, it had been reported as a foliar pathogen of ornamental Rhododendron and Viburnum spp. in Germany and the Netherlands (20,24). Awareness that these plants served as hosts in Europe led to examination of ornamental plants in areas of California infested with $P$. ramorum. It was determined that Rhododendron spp. and many other plants were serving as hosts to $P$. ramorum (2).

Growing awareness of the wide host range of $P$. ramorum and evidence of the pathogen in nurseries caused concerns about the possibility of spreading the pathogen with the movement of ornamentals. California is the leading producer of ornamental plants in the United States and ships plants throughout North America (4). In an attempt to limit the potential spread of $P$. ramorum to other regions, the United States Department of Food and Agriculture-Animal and Plant Health Inspection Service (APHIS) issued the "Order Restricting Movement of Nursery Stock from California Nurseries" in April 2004 (3).

Corresponding author: L. E. Yakabe

E-mail: lyakabe@cdfa.ca.gov

Accepted for publication 9 November 2009.

doi:10.1094/PDIS-94-3-0320

(C) 2010 The American Phytopathological Society
This was followed in October, 2004 by the APHIS "Official Regulatory Protocol for Nurseries Containing Plants Infected with Phytophthora ramorum (Sudden Oak Death)" (2). This "Confirmed Nursery Protocol" delineated monitoring and sanitation procedures for wholesale ornamental nurseries shipping plants outside of their county boundaries. The APHIS procedures call for inspections, $P$. ramorum-free certification, destruction of infested plants, and the elimination of $P$. ramorum from soil or gravel beds where container-grown plants might be placed.

$P$. ramorum has been shown to survive for extended periods in soil, indicating that effective remediation of nurseries harboring the pathogen will require thorough disinfestation of soil media and soil beds. In artificially infested potting media or sand, several studies indicate that propagules of $P$. ramorum, either fully exposed or imbedded in leaf tissue, can remain viable for a year or more $(16,21,23)$. Baiting tests conducted in a California production nursery in 2005 following removal and destruction of an infected Camellia crop detected $P$. ramorum propagules in soil collected from the underlying nursery beds for more than 75 days after removal of plants and plant debris (26).

Agricultural systems have commonly used fumigation to manage soilborne pests $(1,10,11,18,25)$. Hence, when the need arose to eliminate $P$. ramorum from infested nursery soils, APHIS specified several chemical treatment materials in the
Confirmed Nursery Protocol. These included chloropicrin, dazomet, metamsodium, and methyl bromide. Unfortunately, these treatments are problematic in many nursery production situations. Many nurseries are situated within urban centers and cannot accommodate the required buffer zones between fumigation sites and schools or homes, or they have small, inaccessible spaces which are not conducive to conventional soil fumigation equipment. Other problems involve township caps on fumigants that force nursery production to compete with other agricultural crops for use of the material, and the phase-out of methyl bromide. Additionally, container nurseries do not contain typical field soils that are compatible with conventional shank fumigation equipment. Nursery beds under potted plant stock commonly consist of packed gravel over soil, with gravel layers $15 \mathrm{~cm}$ or more in depth. Moreover, the efficacy of the APHIS-recommended soil treatments has not been determined for $P$. ramorum in the nursery environment. For example, monitoring a nursery treated with Basamid (392 kg/ha) and the labelrecommended "water barrier" over the soil surface following application showed that the label treatment did not eradicate $P$. ramorum (26). Finally, there are additional fumigants available or under development such as dimethyldisulfide and iodomethane that might be suitable for nurseries but were not included as options in the APHIS listing of approved materials.

The Confirmed Nursery Protocol does indicate that heat can be used as an alternative to soil fumigation. Soil solarization and steam treatments have been successful in controlling other plant pests in other production systems but little information is available to guide the use of these technologies in container nursery beds (5$8,17,19)$. The main limiting factor in using heat for soil bed sanitation is the ability to deliver heat through the soil profile. Dart et al. (9) were able to isolate $P$. ramorum down to $10 \mathrm{~cm}$ in several commercial nurseries in Washington. In California, $P$. ramorum could be detected at depths down to the hard pan ranging from 15 to $45 \mathrm{~cm}$ (26). The temperatures attained at different soil depths via steam and solar treatments are highly influenced by solar radiation intensity, soil moisture, and soil texture and density (15).

This study was initiated to examine options for elimination of $P$. ramorum from nursery beds. Chemical and nonchemical 
approaches were included to provide more treatment options for affected nurseries. It is hoped that this work will give growers greater flexibility and reliability as they attempt to treat nursery areas infested with P. ramorum.

\section{MATERIALS AND METHODS}

Microcosms. Quarantine restrictions precluded experiments with $P$. ramorum at commercial nurseries or experimental lands. Therefore, microcosms were employed in a controlled laboratory setting to evaluate experimental treatments for control of $P$. ramorum. Most fumigation experiments were conducted in glass Mason jars (Ball, Muncie, IN) of approximately 950-ml capacity whereas heat treatments were tested in smaller glass Mason jars of approximately $118 \mathrm{ml}$ to maximize the rate of heat transfer to the contained soil. Chemicals added as soil drenches were tested in open-ended cone-tainers $(3.8 \mathrm{~cm}$ in diameter by $21 \mathrm{~cm}$ long) (Ray Leach Cone-tainer Nursery, Canby, OR) or in glass cylinders $(11.5 \mathrm{~cm}$ in diameter by 45 $\mathrm{cm}$ long) to allow for bottom drainage. All microcosms were incubated for various times at approximately $22^{\circ} \mathrm{C}$ in a fume hood.

Inoculum and soil. Twelve California isolates of $P$. ramorum, A2 mating type, were used to infest the Yolo fine sandy loam used in these experiments. The soil had a mean particle size distribution of $33 \%$ sand, $47 \%$ silt, and $20 \%$ clay. The $\mathrm{pH}$ was 7.0 and the organic $\mathrm{C}$ content was $0.99 \%$. Eleven isolates were obtained from the $P$. ramorum culture collection of D. M. Rizzo, University of California, Davis. They were isolated originally from foliar, stem, or root lesions found on Rhododendron spp., California bay laurel (Umbellularia californica), tanoak (Lithocarpus densiflorus), or Camellia spp. found in ornamental nurseries or forests. An additional isolate was from soil under infested Camellia stock in a commercial nursery.

To infest soil, two plates of each isolate were grown for 2 weeks at $22^{\circ} \mathrm{C}$ on $\mathrm{V} 8$ agar medium (14). Cultures were microscopically examined to ensure the presence of chlamydospores. Sporangia were also present for some isolates. After 2 weeks, the uncolonized agar was removed and disposed of. The remaining colonized agar was homogenized in a blender for $30 \mathrm{~s}$ with $500 \mathrm{ml}$ of sterile, distilled water. The resulting slurry was incorporated into 70 $\mathrm{kg}$ of the aforementioned soil that had been autoclaved three times for $60 \mathrm{~min}$ over a $72-\mathrm{h}$ period. One to two infestations occurred until a population level of approximately $120 \mathrm{CFU}$ of $P$. ramorum per gram of dry soil was achieved. Concurrently with infestation, sterile distilled water was added to the soil to achieve a final desired soil moisture content of $20 \%$ (vol/vol). Soil moisture content was assessed by drying an aliquot of soil in a $121^{\circ} \mathrm{C}$ oven for $48 \mathrm{~h}$. The moistened, infested soil was thoroughly mixed by hand and allowed to incubate for at least $48 \mathrm{~h}$ before being packed into microcosms. Soil was packed into the microcosms at a bulk density of approximately $1 \mathrm{~g} / \mathrm{ml}$ and a soil column height of approximately $7.5 \mathrm{~cm}$. Infestation levels were verified by dilution plating on CMA-PARP medium as described below.

Liquid fumigants. Individually and in combination, chloropicrin, 1.3-dichloropropene (1,3-D), iodomethane, dimethyldisulfide (DMDS), and metam sodium (Vapam) were first tested at recommended rates using three replications in each of two separate trials. Depending on the ability of the fumigant to eliminate $P$. ramorum propagules, half rates were then tested in triplicate in two separate trials. Fumigant rates were as follows: 1,3-D (112 kg/ha), chloropicrin (56 and 112 kg/ha), DMDS (224 kg/ha), chloropicrin:DMDS (112:224 kg/ha), iodomethane (56 and $112 \mathrm{~kg} / \mathrm{ha}$ ), iodomethane:chloropicrin (56:112 and 112:224 kg/ha), Telone C35 (Dow AgroSciences, Indianapolis, IN), a formulation of 1,3-D and chloropicrin, (370 and 739 liters/ha), and Vapam (a formulation of metam sodium; Amvac, Los Angeles) (350 and 700 liters/ha).

Fumigants were added by injection using a gas-tight, glass syringe (Hamilton Co., Reno, NV) at the surface of the soil column. Injection always occurred at the center of the soil column diameter. Negative controls consisted of infested soil left untreated. The open mouths of the microcosms were covered with 1-mil polyethylene plastic that was secured by rubber bands. The plastic was removed to vent the fumigant 14 days after fumigation or at the minimum restricted entry interval recommended (REI) by the label, which is 5 days after fumigation with chloropicrin, iodomethane, and Telone C35 and 2 days after fumigation with Vapam. All microcosms were allowed to vent for 7 days before sampling. Microcosms were incubated in a completely randomized design in a fume hood at room temperature $\left(22^{\circ} \mathrm{C}\right)$.

Basamid. The efficacy of Basamid (Certis, Columbia, MD), a granular formulation of dazomet, was tested by three methods. In the first method, Basamid granules (112 and $224 \mathrm{~kg} / \mathrm{ha}$ ) were mixed uniformly into the infested soil before being packed into the $950-\mathrm{ml}$ microcosms. Sterile, distilled water $(10 \mathrm{ml})$ was added to the soil column before the microcosms were covered with 1-mil polyethylene. Negative controls consisted of infested soil treated only with $10 \mathrm{ml}$ of sterile, distilled water and covered with polyethylene. The polyethylene plastic was removed to vent the fumigant after 14 days or 2 days, the REI recommended.

In the second method, Basamid granules (224 and $448 \mathrm{~kg} / \mathrm{ha}$ ) were sprinkled onto the surface of the soil column in a 950-ml microcosm. Sterile, distilled water $(80 \mathrm{ml})$ was added to the surface to irrigate the soil and potentially spread the fumigant. Negative controls consisted of infested soil treated only with $80 \mathrm{ml}$ of sterile, distilled water. The microcosms were covered with polyethylene tarp for 2 days.

In the third method, an open-ended glass cylinder was packed with a $3-\mathrm{cm}$ gravel layer at the bottom of the cylinder followed by infested soil to create a soil column of $30 \mathrm{~cm}$ topped with an 8-cm layer of gravel. Basamid granules (224 and 448 $\mathrm{kg} / \mathrm{ha}$ ) were placed on the gravel surface and irrigated with $500 \mathrm{ml}$ of sterile, distilled water. Negative controls consisted of soil columns constructed as described and only irrigated with $500 \mathrm{ml}$ of sterile, distilled water. The soil columns were covered with polyethylene plastic. The polyethylene plastic was removed 2 days after fumigation.

All Basamid treatments were replicated three times in each of two trials. Microcosms were incubated in a completely randomized design in a fume hood at room temperature $\left(22^{\circ} \mathrm{C}\right)$ and vented 7 days before sampling.

Soil drenches. The efficacy of labeled rates of Terraclean (1:1000 dilution; BioSafe Systems, East Hartford, CT) and Zerotol (1:50 dilution; BioSafe Systems), formulations of hydrogen dioxide, were tested by adding infested soil to 164-ml cone-tainers. The soil was packed to a bulk density of $1 \mathrm{~g} / \mathrm{ml}$. Terraclean or Zerotol (50 $\mathrm{ml}$ each) was added to the conetainers, a volume that just yielded drainage from the container bottom. The drenched tubes were incubated for 5 days in a fume hood. Negative controls were cone-tainers filled with infested soil and irrigated with $50 \mathrm{ml}$ of sterilized, distilled water. Two trials of four replications were conducted for each treatment.

Heat treatments. To determine critical exposure temperatures and times for heat treatments of soil to eliminate $P$. ramorum, infested soil was packed into $118-\mathrm{ml}$ jars to a density of $1 \mathrm{~g} / \mathrm{ml}$. The microcosms were sealed with the original Mason jar lids. In two replicates of each treatment, temperature probes (Onset, Sunnyvale, CA) were inserted through the lids to monitor soil temperatures. Microcosms were incubated in dark containers in incubators to achieve 30,40 , and $60^{\circ} \mathrm{C}$ or in a water bath to achieve $80^{\circ} \mathrm{C}$. Untreated controls were incubated on the bench top at $22^{\circ} \mathrm{C}$. Exposure times were 3, 7, 14, 28, 42 , or 56 days, except at $80^{\circ} \mathrm{C}$, where exposure times were 15,45 , and $75 \mathrm{~min}$. Two trials of four replications each were conducted for all treatments.

Soil assays to detect survival. To test for survival of $P$. ramorum following the aforementioned chemical and heat treatments, aliquots of soil were suspended in water and plated onto CMA-PARP (14). 


\section{DISCUSSION}

In these experiments, applications of the soil fumigant materials recommended in the Confirmed Nursery Protocolchloropicrin, dazomet, and metam sodium-applied at recommended rates and used in combination with tarping effectively eliminated detection of $P$. ramorum propagules in soil. Even half label rates combined with a tarping period equal to labeled minimum reentry intervals were effective. These data suggest that nurseries that can accommodate conventional fumigation methods and regulations can expect to eliminate $P$. ramorum in their nursery beds.

Serving as examples, three monitored California nurseries successfully eliminated detectable $P$. ramorum from their infested beds. In all cases, Basamid (392 $\mathrm{kg} / \mathrm{ha}$ ) was tilled into the infested soil and the treated areas were then tarped for 2 weeks. After a week of venting, $P$. ramorum was not detected by baiting tests in soil from the treated areas (26). Followup samples were taken the following year, and $P$. ramorum still could not be detected in any of the treated areas.

Although Basamid was effective when tilled into the soil and tarped according to label directions, many nurseries cannot utilize this method because their nursery beds contain large quantities of gravel. The thick layer of coarse gravel precludes tilling and forces reliance upon the application of Basamid through water infiltration into the soil profile. According to our laboratory experiments, however, $P$. ramorum can be eliminated using this water infiltration method only in small volumes of soil. Although propagules of $P$. ramorum were not detectable in the $7.5-\mathrm{cm}(950-\mathrm{ml}) \mathrm{mi}-$ crocosm, propagules were detectable in the $30-\mathrm{cm}$ open-ended microcosm. One California commercial nursery was successful in using the water infiltration application of Basamid. However, although the beds were covered with $10 \mathrm{~cm}$ of course gravel, the underlying soil was very shallow ( 2 to $3 \mathrm{~cm}$ ) and underlain by a severely compacted mineral layer. Therefore, the results at this nursery site may not be representative (L. E. Yakabe, unpublished).

1,3-D, DMDS, and iodomethane were also tested in these experiments, even though the materials were not included in the Confirmed Nursery Protocol recommendations. Iodomethane, a component of Midas (Arysta LifeScience North American Corporation. Cary, NC), is currently undergoing registration in California. Iodomethane effectively eliminated detection of $P$. ramorum. In contrast, both 1,3-D and DMDS failed to eliminate $P$. ramorum from the microcosms. 1,3-D, a fumigant mainly used for its nematicidal qualities, is effective in combination with chloropicrin. However, as in other studies, 1,3-D has decreased efficacy against fungal and oomycete organisms when used alone (12).
DMDS is a fumigant currently in development and is still unregistered.

Hydrogen dioxide in the formulations of Zerotol and Terraclean was ineffective in these trials. Their chemical characteristics make them unlikely to be an effective eradicant in the soil environment even though they are labeled for soil drenches. Peroxides kill through their oxidizing properties. However, because there are many nontarget substances that can be oxidized in soil, the oxidizing potential is quickly consumed by nontarget substrates. In addition, soil drenches work by contact rather than volatilization and, hence, are inherently less well distributed through the soil profile.

Nurseries unable to use fumigation can consider heat treatments as an alternative for nursery bed remediation. Swain et al. (22) established that a minimum of $40^{\circ} \mathrm{C}$ for $24 \mathrm{~h}$ is lethal to cultures of P. ramorum. Transferring these results into soil, these experiments indicate that $P$. ramorum was not detectable in soil treated with temperatures greater or equal to $40^{\circ} \mathrm{C}$ for 3 days. A maximum exposure time of $15 \mathrm{~min}$ is required for elimination of detectable $P$. ramorum if soil temperatures of $80^{\circ} \mathrm{C}$ can be achieved. These results are consistent with research conducted in sand and potting media. Tooley and Browning (23) reported that chlamydospores were inactivated in sand when incubated at $40^{\circ} \mathrm{C}$ for as little as $24 \mathrm{~h}$. Chlamydospore viability steadily declined when incubated at $35^{\circ} \mathrm{C}$ and eventually were completely inactivated after 7 days. If embedded in plant tissue, chlamydospores required a 2-day exposure at $40^{\circ} \mathrm{C}$ or a 4-day exposure at $35^{\circ} \mathrm{C}$ for inactivation. Using aerated steam in potting media, Linderman and Davis (16) were able to eliminate $P$. ramorum propagules at temperatures greater than $50^{\circ} \mathrm{C}$ when maintained for $30 \mathrm{~min}$. Harnik et al. (13) reported that intact bay leaves infested with $P$. ramorum required 2 weeks of $55^{\circ} \mathrm{C}$ to eliminate $P$. ramorum detection. For these reasons, efforts to remove large plant debris should be taken before heat treatment.

A single, small solarization trial was conducted at a field site used by a University of California Cooperative Extension Advisor in Felton, CA. Plant debris was removed and the infested ground was divided into four treated and four untreated plots. The treated plots were solarized using a 1-mil clear tarp for 6 weeks. Temperature probes were inserted into the soil at depths of 5, 15, and $30 \mathrm{~cm}$. Maximum temperatures recorded at these depths were 40,31 , and $26^{\circ} \mathrm{C}$, respectively. Before solarization, $P$. ramorum was detected by soil baiting with Rhododendron leaves throughout the soil profile down to $30 \mathrm{~cm}$. $P$. ramorum was not detectable by soil baiting at the end of the trial in the solarized plots but was detectable in the untreated plots. These results suggest that prolonged exposure to sublethal temperatures of below $40^{\circ} \mathrm{C}$ may eventually eliminate propagules of $P$. ramorum.

Unevaluated soil treatments recommended in the Confirmed Nursery Protocol have made remediation of $P$. ramoruminfested nurseries difficult and unreliable. Although the quarantine status of $P$. ramorum has made controlled field trials infeasible, in vitro evaluations provide evidence that the Confirmed Nursery Protocol recommendations can be effective. Iodomethane, a fumigant not included in the recommendations, is also effective. Basamid efficacy is dependent on proper application. For reliable efficacy, Basamid should be fully incorporated into the soil and then tarped. Nurseries unable to fumigate must rely on heating technologies. Steam sterilization and solarization can be effective if adequate heat can be delivered to $P$. ramorum propagules. In conjunction with data from other studies, experiments indicate that soil temperatures of at least $40^{\circ} \mathrm{C}$ should be sustained for several days. If higher temperatures are achieved, reliability will be increased and less treatment time will be required. The effects of common nursery substrates such as gravel layers and compacted soil remain uncertain in both fumigation and heat treatments. Further experimentation should be conducted under field conditions to adequately explore remediation treatments.

\section{ACKNOWLEDGMENTS}

We thank H. Ajwa, S. Tjosvold, and D. Chambers from the University of California Cooperative Extension for providing fumigation materials and expertise in the lab and field; C. Elmore for his technical expertise; the several anonymous commercial nurseries that have allowed us to conduct experiments and monitor fumigations; and the United States Department of Agriculture Forest Service, Pacific Southwest Research Station for their financial support.

\section{LITERATURE CITED}

1. Ajwa, H. A., Trout, T., Nueller, J., Wilhelm, S D., Nelson, S. D., Soppe, R., and Shatley, D. 2002 Application of alternative fumigants through drip irrigation systems. Phytopathology 92:1349-1355.

2. Anonymous. 2004. Official Regulatory Protocol for Nurseries Containing Plants Infected with Phytophthora ramorum (Sudden Oak Death). United States Department of Agriculture-Animal and Plant Health Inspection Service, Beltsville, MD.

3. Anonymous. 2004. Order Restricting Movement of Nursery Stock from California Nurseries. United States Department of AgricultureAnimal and Plant Health Inspection Service, Beltsville, MD.

4. Anonymous. 2006. California Agricultural Resource Directory, 2006. California Department of Food and Agriculture, Sacramento.

5. Baker, K. F, and Roistacher, C. N. 1957. Heat treatment of soil. Pages 123-137 in: The UC System for Producing Healthy ContainerGrown Plants. UC Manual 23. University of California, Agricultural Experiment Station Extension Service.

6. Benlioglu, S., Boz, O., Yldz, A., Kaskavalc G. and Benlioglu, K. 2005. Alternative soil solarization treatments for the control of soil-borne diseases and weeds of strawberry in the west- 
ern Anatolia of Turkey. J. Phytopathol. 153:423-430

7. Chellemi, D. O., Olson, S. M., and Mitchell, D. J. 1994. Effect of soil solarization and fumigation on survival of soilborne pathogens on tomato in northern Florida. Plant Dis. 78:11671172.

8. Coelho L., Chellemi D. O., and Mitchell, D. J. 1999. Efficacy of solarization and cabbage amendment for the control of Phytophthora spp. in North Florida. Plant Dis. 83:293-299.

9. Dart, N. L., Chastagner, G. A., Rugarber, E. F., and Riley, K. L. 2007. Recovery frequency of Phytophthora ramorum and other Phytophthora spp. in the soil profile of ornamental retail nurseries. Plant Dis. 91:1419-1422.

10. Duniway, J. D. 2002. Status of chemical alternatives to methyl bromide for pre-plant fumigation of soil. Phytopathology 92:1337-1343.

11. Eayer, C. G., Sims, J. J., Ohr, H. D., and Mackey, B. 2000. Evaluation of methyl iodide for control of peach replant disorder. Plant Dis. 84:1177-1179.

12. Elmore, C. L., MacDonald, J. D., Ferris, H., Chase, A., Ajwa, H., Robb, K., Wilen, C., Zasada, I., Fennimore, S., and Tjosvold, S. 2007. Soil Pests of Floriculture Crops and Potential Control with Methyl Bromide Alternatives in California. California Cut Flower Commission, Capitola, CA.

13. Harnik, T. Y., Mejia-Chang, M., Lewis, J., and
Garbelotto, M. 2004. Efficacy of heat-based treatments in eliminating the recovery of the sudden oak death pathogen (Phytophthora ramorum) from infected California bay laurel leaves. HortScience 39:1677-1680.

14. Jeffers, S. N., and Martin, S. B. 1986. Comparison of two media selective for Phytophthora and Pythium species. Plant Dis. 70:1068-1043.

15. Katan, J., and DeVay, J. E. 1991. Soil Solarization. CRC Press, Boca Raton, FL.

16. Linderman, R. G., and Davis, E. A. 2008. Eradication of Phytophthora ramorum and other pathogens from potting medium or soil by treatment with aerated steam or fumigation with metam sodium. HortTechnology 18:106110.

17. Miller, P. M. 1955 . V-8 juice agar as a general purpose medium for fungi and bacteria. Phytopathology 45:461-462.

18. Noling, J. W. 1997. Role of soil fumigants in Florida agriculture. Pages 14-24 in: :Fumigants: Environmental Fate, Exposure, and Analysis. J. N. Seiber, J. A. Knutsen, J. E. Woodrow, N. L. Wolfe, M. V. Yates, and S. R. Yates, eds. American Chemical Society, Washington, DC

19. Pinkerton, J. N. Ivors, K. L., Reeser, P. W., Bristow, P. R., and Windom, G. E. 2002. The use of soil solarization for the management of soilborne plant pathogens in Western Oregon. Plant Dis. 84:952-960.
20. Rizzo, D. M., Garbelotto, M., Davidson, J. M Slaughter, G. W., and Koike, S. T. 2002. Phytophthora ramorum as the cause of extensive mortality of Quercus spp. and Lithocarpus densiflorus in California. Plant Dis. 86:205214.

21. Shishkoff, N. 2007. Persistence of Phytophthora ramorum in soil mix and roots of nursery ornamentals. Plant Dis. 91:1245-1249.

22. Swain, S., Harnik, T., Mejia-Chang, M., Hayden, K., Bakx, W., Creque, J., and Garbelotto, M.. 2006. Composting is an effective treatment option for sanitization of Phytophthora ramorum-infected plant material. J. Appl. Microbiol. 101:815-827.

23. Tooley, P. W., Browning, M., and Berner, D. 2008. Recovery of Phytophthora ramorum following exposure to temperature extremes. Plant Dis. 92:431-437.

24. Werres, S., Marwitz, R., Man In'T Veld, W. A. De Cock, A. W. A. M., Bonants, P. J. M., De Weerdt, M., Themann, K., Ilieva, E., and Bayen, R. P. 2001. Phytophthora ramorum sp. nov., a new pathogen on Rhododendron and Viburnum. Mycol. Res. 105:1155-1165.

25. Wilhelm, S., and Paulus, A. O. 1980. How soil fumigation benefits the California strawberry industry. Plant Dis. 64:264-270.

26. Yakabe, L. E., and MacDonald, J. D. 2006. Evaluation of soil treatments for the elimination of Phytophthora ramorum from nursery beds. (Abstr.) Phytopathology 96:S127. 